\section{European Free Trade Association (EFTA)}

History and Membership. The Stockholm Convention establishing the Association entered into force on 3 May 1960. Founder members were Austria, Denmark, Norway, Portugal, Sweden, Switzerland and the UK. With the accession of Austria, Denmark, Finland, Portugal, Sweden and the UK to the EU, EFTA was reduced to four member countries: Iceland, Liechtenstein, Norway and Switzerland. In June 2001 the Vaduz Convention was signed. It liberalizes trade further among the four EFTA States in order to reflect the Swiss-EU bilateral agreements.

Activities. Free trade in industrial goods among EFTA members was achieved by 1966. Co-operation with the EU began in 1972 with the signing of free trade agreements and culminated in the establishment of a European Economic Area (EEA), encompassing the free movement of goods, services, capital and labour throughout EFTA and the EU member countries. The Agreement was signed by all members of the EU and EFTA on 2 May 1992, but was rejected by Switzerland in a referendum on 6 Dec. 1992. The agreement came into force on 1 Jan. 1994.

The main provisions of the EEA Agreement are: free movement of products within the EEA from 1993 (with special arrangements to cover food, energy, coal and steel); EFTA to assume EU rules on company law, consumer protection, education, the environment, research and development, and social policy; EFTA to adopt EU competition rules on anti-trust matters, abuse of a dominant position, public procurement, mergers and state aid; EFTA to create an EFTA Surveillance Authority and an EFTA Court; individuals to be free to live, work and offer services throughout the EEA, with mutual recognition of professional qualifications; capital movements to be free with some restrictions on investments; EFTA countries not to be bound by the Common Agricultural Policy (CAP) or Common Fisheries Policy (CFP).

The EEA-EFTA states have established a Surveillance Authority and a Court to ensure implementation of the Agreement among the EFTA-EEA states. Political direction is given by the EEA Council which meets twice a year at ministerial level, while ongoing operation of the Agreement is overseen by the EEA Joint Committee. Legislative power remains with national governments and parliaments.

EFTA has formal relations with several other states. Declarations on co-operation were signed with Hungary, former Czechoslovakia and Poland (1990), Bulgaria, Estonia, Latvia, Lithuania and Romania (1991), Slovenia and Albania (1992), Egypt, Morocco and Tunisia (1995), the former Yugoslav Republic of Macedonia and the Palestine Liberation Organization (1996), Jordan and Lebanon (1997), Croatia, the Gulf Co-operation Council, Serbia and Montenegro and MERCOSUR (2000) and Algeria (2002). Free trade agreements have been signed with Turkey (1991), Israel and Czechoslovakia (1992, with protocols on succession with the Czech Republic and Slovakia in 1993), Poland and Romania (1992), Bulgaria and Hungary (1993), Estonia, Latvia, Lithuania and Slovenia (1995), Morocco (1997), the Former Yugoslav Republic of Macedonia and Mexico (2000), Jordan and Croatia (2001), Singapore (2002), Chile (2003) and Lebanon and Tunisia (2004). In Dec. 1998 an interim free trade agreement was signed with the Palestinian Authority and talks on an agreement began with Egypt. Negotiations on free trade agreements are ongoing with Canada, Egypt and Cyprus.

Organization. The operation of the free trade area among the EFTA states is the responsibility of the EFTA Council which meets regularly at ambassadorial level in Geneva. The Council is assisted by a Secretariat and standing committees. Each EFTA country holds the chairmanship of the Council for six months. For EEA matters there is a separate committee structure.
Brussels Office (EEA matters, press and information): 12-16 Rue Joseph II, B-1000 Brussels.

Headquarters: 9-11 rue de Varembé, 1211 Geneva 20,

Switzerland.

Website: http://www.efta.int

e-mail: efta-mailbox@secrbru.efta.be

Secretary-General: William Rossier (Switzerland).

Publications. Convention Establishing the European Free Trade Association; EFTA Annual Report; EFTA Fact Sheets: Information Papers on Aspects of the EEA; EFTA Bulletin.

\section{European Space Agency (ESA)}

History. Established in 1975, replacing the European Space Research Organization (ESRO) and the European Launcher Development Organization (ELDO).

Members. Austria, Belgium, Denmark, Finland, France, Germany, Greece, Ireland, Italy, Luxembourg, the Netherlands, Norway, Portugal, Spain, Sweden, Switzerland, United Kingdom. Canada takes part in some projects under a co-operation agreement.

Activities. ESA is the intergovernmental agency in Europe responsible for the exploitation of space science, research and technology for exclusively peaceful purposes. Its aim is to define and put into effect a long-term European space policy that allows Europe to remain competitive in the field of space technology. It has a policy of co-operation with various partners on the basis that pooling resources and sharing work will boost the effectiveness of its programmes. Its space plan covers the fields of science, Earth observation, telecommunications, navigation, space segment technologies, ground infrastructures, space transport systems and microgravity research.

Headquarters: 8-10 rue Mario Nikis, 75738 Paris Cedex 15,

France.

Website: http://www.esa.int

e-mail: contactesa@esa.int

Director-General: Jean-Jacques Dordain (France).

\section{CERN - The European Organization for Nuclear Research}

Founded in 1954, CERN is the world's leading particle physics research centre. Bystudying the behaviour of nature's fundamental particles, CERN aims to find out what our Universe is made of and how it works. CERN's biggest accelerator, the Large Hadron Collider (LHC), is scheduled for completion in 2007. One of the beneficial byproducts of CERN activity is the Worldwide Web, developed at CERN to give particle physicists easy access to shared data. One of Europe's first joint ventures, CERN now has a membership of 20 member states: Austria, Belgium, Bulgaria, Czech Republic, Denmark, Finland, France, Germany, Greece, Hungary, Italy, the Netherlands, Norway, Poland, Portugal, Slovak Republic, Spain, Sweden, Switzerland, United Kingdom. Some 6,500 scientists, half of the world's particle physicists, use CERN's facilities. They represent 500 institutions and 85 nationalities.

Address: CH-1211 Geneva 23, Switzerland.

Website: http://www.cern.ch

Director-General: Dr Robert Aymar (France). 